\title{
Survival patterns of Dekkera bruxellensis in wines and inhibitory effect of sulphur dioxide
}

\author{
A. Barata, J. Caldeira, R. Botelheiro, D. Pagliara, M. Malfeito-Ferreira *, V. Loureiro \\ Laboratório de Microbiologia, Departamento de Botânica e Engenharia Biológica, Instituto Superior de Agronomia, \\ Technical University of Lisbon, 1349-017 Lisboa, Portugal
}

Received 23 February 2007; received in revised form 1 October 2007; accepted 6 November 2007

\begin{abstract}
The wine spoilage yeast species Dekkera bruxellensis, after inoculation in red wines, displayed three survival patterns characterized by: i) initial lag phase followed by growth and sequential death; ii) initial death phase leading to reduced viable counts followed by growth and sequential death; and iii) death phase leading to complete loss of viability. These survival patterns were observed for the same strain in different dry red wine blends with $12 \%(\mathrm{v} / \mathrm{v})$ ethanol and $\mathrm{pH} 3.50$, in the absence of free sulphur dioxide. For the same wine blend, these patterns also varied with the tested strain.

Under laboratory conditions the addition of $150 \mathrm{mg} / \mathrm{l}$ of potassium metabisulphite (PMB) to dry red wine with $12 \%(\mathrm{v} / \mathrm{v})$ ethanol and $\mathrm{pH} 3.50$ reduced initial cell counts by more than 6 logarithmic cycles, inducing full death within less than 24 h. Winery trials showed that $D$. bruxellensis blooms were only prevented in the presence of about $40 \mathrm{mg} / \mathrm{l}$ of free sulphur dioxide in dry red wine, with $13.8 \%$ (v/v) ethanol and $\mathrm{pH} 3.42$, matured in oak barrels. These different amounts of PMB and sulphur dioxide corresponded to about $1 \mathrm{mg} / \mathrm{l}$ of molecular sulphur dioxide. Our results therefore demonstrate that the control of populations of D. bruxellensis growing in red wine can only be achieved under the presence of relatively high doses of molecular sulphur dioxide.
\end{abstract}

(C) 2007 Elsevier B.V. All rights reserved.

Keywords: Dekkera/Brettanomyces bruxellensis; Sulphur dioxide; Cell death; Wine; Spoilage yeasts; Oak barrels

\section{Introduction}

The yeasts of the species Dekkera bruxellensis, or its anamorph Brettanomyces bruxellensis, are responsible for serious economic losses in the wine industry owing to their ability to spoil wines by the production of ethylphenols (Loureiro and Malfeito-Ferreira, 2006). During the last decade these yeasts have been increasingly studied by many research teams aiming to understand their spoiling abilities and to establish control measures (Suárez et al., 2007). Despite this interest there are still issues which are not clearly understood, such as the real effect of preservatives on the inactivation of $D$. bruxellensis populations in wines. The main preservative used in the wine industry is sulphur dioxide (Ribéreau-Gayon et al., 2006)

\footnotetext{
* Corresponding author. Tel.: +351 213653448; fax: +351 213653238
}

E-mail address: mmalfeito@isa.utl.pt (M. Malfeito-Ferreira). but reports about its effect on $D$. bruxellensis inactivation are often contradictory. This yeast is recovered mainly from wines not protected by sulphur dioxide (Heresztyn, 1986) and some authors refer its sensitivity to values higher than $30 \mathrm{mg} / 1$ (Gerbaux et al., 2002; Chatonnet et al., 1992, 1993). Others state that it should be regarded as resistant (Van der Walt and van der Kerken, 1961; Gaia, 1987; Ciolfi, 1991) and growth has been reported under more than $30 \mathrm{mg} / 1$ of free sulphur dioxide (Froudière and Larue, 1989). This controversy probably arises from the lack of studies under comparable situations and strain behaviour variability. Despite this controversy, in Australian wines levels of free sulphur dioxide have increased in the last years probably because of the adoption of stricter measures to control Dekkera/Brettanomyces (Godden and Gishen, 2005). These authors established a possible link between this fact and the decrease in wine's mean 4-ethylphenol concentrations observed during the 1996-2002 period. We have shown 
that 4-ethylphenol is not produced in the absence of growing D. bruxellensis populations (Dias et al., 2003) and so their inactivation results in the lack of 4-ethylphenol production. The present work was therefore aimed at establishing the growth behaviour of $D$. bruxellensis in wines and evaluating the effect of sulphur dioxide on the viability of a wide range of strains. The conditions used were intended to mimic winery practice in order to establish technological measures to control its activity.

\section{Materials and methods}

\subsection{Yeast strains and maintenance conditions}

The strains of D. bruxellensis tested were either obtained from culture collections or isolated from wine-related environments by our laboratory (Table 1). The Dekkera spp. strains were maintained in slants of GYP medium (20 g/l glucose (Merck, Darmstadt, Germany), $5 \mathrm{~g} / \mathrm{l}$ yeast extract (Difco Laboratories, Detroit, USA), $10 \mathrm{~g} / 1$ peptone (Difco) and $20 \mathrm{~g} / 1$ agar, $\mathrm{pH}$ 6.0) added of $5 \mathrm{~g} / \mathrm{l}$ of calcium carbonate (Merck), at $4{ }^{\circ} \mathrm{C}$. The strain Saccharomyces cerevisiae ISA 1000 and the type strain of $B$. anomalus ISA 1652 were used for comparative purposes.

\subsection{Tolerance to ethanol and potassium metabisulphite (PMB)}

The tolerance evaluation to ethanol and PMB was performed according to the liquid medium assimilation tests described by Kurtzman and Fell (1998). Briefly, fresh cultures obtained by growth on GYP slants (24-48 h) were dispersed in $5 \mathrm{ml}$ of Ringer diluent (Oxoid, Basingstoke, England) contained in test

Table 1

Origin of analyzed strains

\begin{tabular}{|c|c|c|}
\hline Species & Strains ISA $^{a}$ & Source $^{\mathrm{a}}$ \\
\hline $\begin{array}{c}\text { Saccharomyces } \\
\text { cerevisiae }\end{array}$ & 1000 & $\begin{array}{l}\text { IGC } 4072 \text {, Fermivin, commercial } \\
\text { starter }\end{array}$ \\
\hline $\begin{array}{l}\text { Brettanomyces } \\
\text { anomalus }\end{array}$ & 1652 & $\begin{array}{l}\text { CBS } 77^{\mathrm{T}} \mathrm{b}, \text { IGC } 5153 \\
\text { Stout beer }\end{array}$ \\
\hline \multirow{16}{*}{$\begin{array}{l}\text { Dekkera } \\
\quad \text { bruxellensis }\end{array}$} & 1649 & CBS $72^{\mathrm{T}}$, IGC 4179 , Lambic beer \\
\hline & 1146 & UCD 605 \\
\hline & 1327,1600 & Sparkling white wines (Portugal) \\
\hline & $1700,1703,1791,2128$ & Red wines (Dão, Portugal) \\
\hline & 1717 & White wine (Estremadura, Portugal) \\
\hline & $2101,2102,2104,2132$ & Red wines (Alentejo, Portugal) \\
\hline & $2114,2115,2116,2120$ & Red wines (Ribatejo, Portugal) \\
\hline & $2206,2208,2210$ & Red wine (Estremadura, Portugal) \\
\hline & 2150 & Red wine (Portugal) \\
\hline & 2172 & Red wine (Spain) \\
\hline & 2173,2174 & Red wine (California, USA) \\
\hline & $2202,2203,2204,2205$ & Red wines (ISVEA, Italy) \\
\hline & 2207 & Red wine (Terras do Sado, Portugal) \\
\hline & $2209,2211,2212$ & Red wines (Douro, Portugal) \\
\hline & 2297,2307 & Barrique wood after red wine storage \\
\hline & 2298 & Insect in winery \\
\hline
\end{tabular}

${ }^{\text {a }}$ ISA (Instituto Superior de Agronomia, Lisbon, Portugal), IGC (Gulbenkian Institute of Science, Oeiras, Portugal), CBS (Centraalbureau voor Shimmelcultures, Delft, The Netherlands), UCD (University of California, Davis, USA), ISVEA (Istituto per lo Sviluppo Viticolo Enologico ed Agroindustriale, Tuscany, Italy).

b Type strain. tubes (16 mm diameter). A card with black lines approximately $0.75 \mathrm{~mm}$ wide was used to check the turbidity of the yeast suspension. When the black lines became visible through the tube as dark bands, one drop was delivered, with a sterile Pasteur pipette, to each of the growth broths' test tubes. The growth media consisted of $4 \mathrm{ml}$ Yeast Nitrogen Base with amino-acids (YNB, Difco) (6.7 g/l) supplemented with glucose $(20 \mathrm{~g} / \mathrm{l})$ and different levels of ethanol (Merck) $(8,10,12,13$, $14,14.5,15,15.5,16,16.5,17$ and $17.5 \%$ v/v) or PMB (Merck) $(40,60,70,80,90,100,120,140,160,180,200$ and $210 \mathrm{mg} / 1)$, at initial $\mathrm{pH} 3.50$. For each concentration growth was positive when the lines of the black cardboard became diffuse (value ++ ). Then 3 drops of yeast suspension were inoculated in the following higher ethanol or PMB concentration. After 3 weeks of incubation at $25^{\circ} \mathrm{C}$, growth was considered negative when black lines were distinguishable but with indistinct edges visible through the test tube (value + ). In this way the results reflect the tolerance of cells adapted to the antimicrobial agent.

\subsection{Growth in wines and effect of ethanol and $p H$}

A loopful of fresh culture (24-48 h) was used to inoculate $50 \mathrm{ml}$ of culture broth $(6.7 \mathrm{~g} / 1 \mathrm{YNB}, 20 \mathrm{~g} / 1$ glucose, $10 \%$ (v/v) ethanol, $\mathrm{pH}$ 3.50) previously filter-sterilised through a cellulose acetate membrane $(0.22 \mu \mathrm{m}$ pore size, $47 \mathrm{~mm}$ diameter, Millipore). Incubation occurred at $25{ }^{\circ} \mathrm{C}$ with orbital shaking (120 rpm). Growth was followed by measurement of the absorbance at $640 \mathrm{~nm}$. When OD was about 0.5 units, red wine (100 $\mathrm{ml}$ in $250 \mathrm{ml}$ cotton-plugged Erlenmeyer flasks) was inoculated to give an initial population of $10^{4}$ cells $/ \mathrm{ml}$. Incubation was performed by orbital shaking $(150 \mathrm{rpm})$ at $25^{\circ} \mathrm{C}$. During incubation, wine samples were decimally diluted and cellular viability determined by surface-plating $0.1 \mathrm{ml}$ onto GYP medium, in duplicate. Metabolically-active cells were estimated by methylene blue staining $(0.1 \mathrm{~g} / 1$ methylene blue (Merck) in a $20 \mathrm{~g} / 1$ sodium citrate (Sigma) solution) following the protocol described by Thomas et al. (1978). Experimental wines were obtained by a blend of several commercial red wines without residual sugar. The free sulphur dioxide present in the blends was removed by the addition of acetaldehyde (RibéreauGayon et al., 2006). The ethanol content was adjusted to $8 \%$, $10 \%$ or $12 \%(\mathrm{v} / \mathrm{v})$ with a solution of $5 \mathrm{~g} / \mathrm{l}$ of tartaric acid (Merck) or 99\% pure ethanol (Merck). The $\mathrm{pH}$ value was adjusted to 3.00 or 3.50 with concentrated $\mathrm{NaOH}$ (Merck) or $\mathrm{HCl}$ (Merck). The final wine blends were sterilised by filtration through cellulose acetate membranes $(0.22 \mu \mathrm{m}$ pore size, $47 \mathrm{~mm}$ diameter, Millipore).

\subsection{Effect of potassium metabisulphite (PMB) in wines}

Yeast suspensions were prepared as described before (lines 111-117) and inoculated in a red wine blend to give an initial count of about $10^{4}$ cells $/ \mathrm{ml}$. Blends (50 $\mathrm{ml}$ of wine) were maintained in $100 \mathrm{ml}$ Erlenmeyer flasks plugged with rubber stoppers. These stoppers were perforated by cotton-plugged hypodermic needles to minimize evaporation losses. Incubation was carried out at $25^{\circ} \mathrm{C}$ without shaking for up to 10 days. 
Table 2

Maximum ethanol concentration (\% v/v) allowing growth in YNB broth with glucose $(20 \mathrm{~g} / \mathrm{l})$ and initial $\mathrm{pH} 3.50$, at $25^{\circ} \mathrm{C}$, for a maximum incubation period of 29 days

\begin{tabular}{|c|c|c|}
\hline Species & Strains & $\begin{array}{l}\text { Maximum } \\
\text { concentration }\end{array}$ \\
\hline $\begin{array}{c}\text { Saccharomyces } \\
\text { cerevisiae }\end{array}$ & ISA $1000^{\mathrm{a}}$ & 16.0 \\
\hline $\begin{array}{c}\text { Brettanomyces } \\
\text { anomalus }\end{array}$ & ISA $1652^{\mathrm{T}^{\mathrm{b}}}$ & 8.0 \\
\hline \multirow{4}{*}{$\begin{array}{l}\text { Dekkera } \\
\quad \text { bruxellensis }\end{array}$} & ISA $2116,2211^{\mathrm{a}}$ & 15.0 \\
\hline & $\begin{array}{l}\text { ISA } 1600,1649^{\mathrm{T}}, 1700,1717,1791,2101, \\
2102,2114,2115,2128,2172,2174,2204, \\
2206,2207,2208^{\mathrm{a}}, 2209,2210,2212,2298\end{array}$ & 14.5 \\
\hline & ISA $1146,1327,2173,2203,2205^{\mathrm{a}}$ & 14.0 \\
\hline & ISA 2104, 2202 & 13.5 \\
\hline
\end{tabular}

${ }^{a}$ Where the duplicates did not show the same results, the highest score is presented. The difference between the duplicates was no higher than $0.5 \%(\mathrm{v} / \mathrm{v})$.

b Type strain.

Cellular viability was periodically measured by surface-plating $0.1 \mathrm{ml}$ of wine sample onto GYP agar. PMB (100 mg/l) was added to wines when about $10^{6}-10^{7} \mathrm{CFU} / \mathrm{ml}$ were attained. The percentage of active cells was measured by methylene blue staining, as described before. At the end of the experiment, cell viability was determined in the remaining wine volume by plating onto GYP agar after $0.22 \mu \mathrm{m}$ membrane filtration (Millipore). Results are the mean of two independent experiments.

A selected group of strains resistant to $100 \mathrm{mg} / \mathrm{l}$ PMB (ISA 2101, 2172 and 2298) was further tested against the addition of 100,150 and $200 \mathrm{mg} / \mathrm{l}$ of PMB during the growth phase, as described before. In order to test the influence of different cellular adaptation to wine, these strains were also previously grown in red wine $(6 \%(\mathrm{v} / \mathrm{v})$ ethanol, $\mathrm{pH} 3.50$, without free sulphur dioxide), inoculated in dry red wine blends $(12 \%(\mathrm{v} / \mathrm{v})$ ethanol, $\mathrm{pH} 3.50$, without free sulphur dioxide) and challenged against $100 \mathrm{mg} / \mathrm{PMB}$, by use of the protocol described before.

\subsection{Effect of sulphur dioxide at winery level}

Winery trials were conducted in commercial 2004 dry red wine $(13.8 \%$ (v/v) ethanol, $\mathrm{pH} 3.42)$ stored in new French oak barrels (225 1) maintained under 4 levels of free sulphur dioxide targeted at $25 \mathrm{mg} / 1,30 \mathrm{mg} / \mathrm{l}, 45 \mathrm{mg} / 1$ and $60 \mathrm{mg} / \mathrm{l}$. Sulphur dioxide concentrations were checked every 15 days with the iodine titration method recommended by the International Organization of the Vine and Wine (OIV). Sulphur tablets were used to adjust the free sulphur dioxide concentration to the required level (Ribéreau-Gayon et al., 2006). Samples were taken with a sterile pipette $(200 \mathrm{ml})$ from the wine surface and from the barrel bottom, serially diluted with Ringer solution or concentrated by membrane filtration $(0.22 \mu \mathrm{m}$ pore size, $47 \mathrm{~mm}$ diameter, Millipore). Viable cells were counted after inoculation on Dekkera/Brettanomyces differential medium (DBDM) plates as described by Rodrigues et al. (2001). Small pinpoint olivegreen colonies on plates releasing a phenolic smell were microscopically examined after incubation for 12 days at $25^{\circ} \mathrm{C}$. The reported counts $(\mathrm{CFU} / \mathrm{ml})$ corresponded to colonies showing cells with shapes characteristic of D. bruxellensis (presence of boat or ogival shapes and bud scars).

\section{Results}

\subsection{Ethanol and PMB tolerance screenings}

The tolerance to ethanol and PMB of Dekkera spp. and $S$. cerevisiae, measured in synthetic culture media at initial $\mathrm{pH}$ 3.50, is shown in Tables 2 and 3, respectively. S. cerevisiae was relatively more tolerant to ethanol, growing under $16 \%(\mathrm{v} / \mathrm{v})$, while the 2 most resistant strains of $D$. bruxellensis grew under $15.0 \%(\mathrm{v} / \mathrm{v})$ ethanol. Most strains of this species (20 over 29) grew under $14.5 \%(\mathrm{v} / \mathrm{v})$ ethanol. The most sensitive strains tested (2 over 29$)$ grew in the presence of $13.5 \%(\mathrm{v} / \mathrm{v})$ ethanol. The type strain of $B$. anomalus was the most ethanol-sensitive strain, being inhibited by the presence of ethanol higher than $8 \%$ $(\mathrm{v} / \mathrm{v})$. Concerning PMB, the most resistant strain was also S. cerevisiae, growing under $200 \mathrm{mg} / \mathrm{l}$ of PMB, while 17 strains of $D$. bruxellensis grew in the range of 60 to $90 \mathrm{mg} / 1$. Six strains did not grow under the lowest PMB concentration tested $(40 \mathrm{mg} / \mathrm{l})$. B. anomalus was able to grow under $90 \mathrm{mg} / \mathrm{l}$ of PMB.

\subsection{Behaviour of yeast populations in wines}

Fig. 1 shows the survival patterns of two D. bruxellensis strains in a dry red wine blend as a function of ethanol and $\mathrm{pH}$. Three different patterns were observed: i) initial lag phase followed by growth and death under a bell-shaped curve; ii) initial death phase followed by growth and death under a bell-shaped curve; iii) death phase after inoculation without viability recovery. The extent of the lag phase or the magnitude of death rate depends on the stress exerted on yeast populations. For both strains and $\mathrm{pH}$ values, growth was observed under $8 \%$ $(\mathrm{v} / \mathrm{v})$ ethanol and death under $14 \%(\mathrm{v} / \mathrm{v})$. Only the strain ISA 1791 was able to grow after an initial death phase at $12 \%(\mathrm{v} / \mathrm{v})$ ethanol and $\mathrm{pH}$ 3.50. This initial death phase was characterized

Table 3

Maximum initial potassium metabisulphite concentration (mg/l) allowing growth in YNB broth with glucose $(20 \mathrm{~g} / \mathrm{l})$ and initial $\mathrm{pH} 3.50$, at $25^{\circ} \mathrm{C}$, for a maximum incubation period of 21 days

\begin{tabular}{llc}
\hline Species & Strains & $\begin{array}{c}\text { Maximum } \\
\text { concentration }\end{array}$ \\
\hline $\begin{array}{c}\text { Saccharomyces } \\
\text { cerevisiae }\end{array}$ & ISA 1000 & 200 \\
$\begin{array}{c}\text { Brettanomyces } \\
\text { anomalus }\end{array}$ & ISA $1652^{\mathrm{T}}$ a, b & 90 \\
$\begin{array}{c}\text { Dekkera } \\
\text { bruxellensis }\end{array}$ & ISA $1700^{\mathrm{a}}$ & 90 \\
& ISA 2114, 2206, 2212, 2209 & \\
& ISA $1791,2102,2203,2211,2298$ & 80 \\
& ISA $1327,1717,2115,2128,2174,2202^{\mathrm{a}}$, & 60 \\
& 2207 & 40 \\
& ISA $1146,1649^{\mathrm{T}}, 2101,2116,2173,2210$ & $<40$ \\
\hline
\end{tabular}

a Where the duplicates did not show the same results, the highest score is presented. The difference between the duplicates was no higher than $10 \mathrm{mg} / \mathrm{l}$.

b Type strain. 

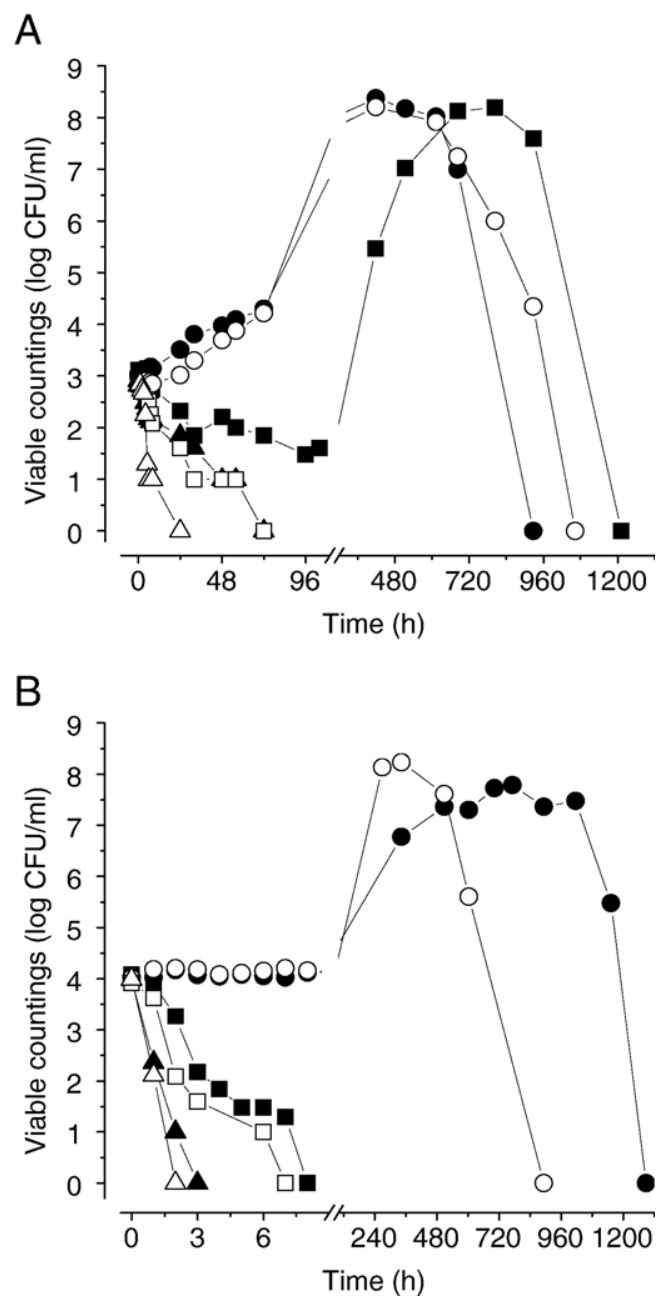

Fig. 1. Viability of Dekkera bruxellensis ISA 1791 (filled symbols) and ISA 2150 (open symbols) inoculated in wine blends at $\mathrm{pH} 3.50$ (A) and $\mathrm{pH} 3.00$ (B) at $8(\boldsymbol{\bullet}, \mathrm{O}), 12(\boldsymbol{\square}, \square)$ and $14(\boldsymbol{\Lambda}, \Delta) \%(\mathrm{v} / \mathrm{v})$ ethanol. The value 0 for viable countings indicates the absence of colonies in the volume of $0.1 \mathrm{ml}$ of wine sample.

by the similarity between the viable counts obtained by plating and the numbers of metabolically-active cells estimated by the methylene blue stain. Contrarily, the viable counts determined during the death occurring after the stationary phase were at least 10 times lower than the number of metabolically-active cells (results not shown).

The yeast behaviour was determined in several other dry red wine blends with ethanol and $\mathrm{pH}$ adjusted to $12 \%(\mathrm{v} / \mathrm{v})$ and 3.50 , in the absence of free sulphur dioxide. Under these conditions, the strain ISA 1791 showed either full death or growth depending on the wine blend (results not shown).

\subsection{Effect of $P M B$ under laboratory conditions}

The previous experiments with different red wine blends prepared with equal concentrations of ethanol $(12 \% \mathrm{v} / \mathrm{v})$ and $\mathrm{pH}$ values $(\mathrm{pH} 3.50)$ induced different behaviours for the same D. bruxellensis strain. The behaviour of different strains must therefore be determined simultaneously with the same wine blend to obtain comparable results. To mimic the effect of PMB on wine-adapted yeast populations, the preservative was added when cell counts attained $10^{6}-10^{7} \mathrm{CFU} / \mathrm{ml}$.

A total of 19 strains were inoculated in a dry red wine blend $(12 \%(\mathrm{v} / \mathrm{v})$ ethanol and $\mathrm{pH} 3.50)$, resulting in different behaviours. The type strain ISA 1649 died within $24 \mathrm{~h}$ of inoculation and strain ISA $2121 \mathrm{did}$ not attain more than $2.5 \times 10^{2} \mathrm{CFU} / \mathrm{ml}$ in the course of the experiment. The behaviour of the remaining 17 strains is illustrated by the growth pattern of 4 strains in Fig. 2. While some strains exhibited a significant viability loss after wine inoculation followed by cellular growth, others initiated the growth phase without showing a decrease in viable counts. The values of minimum and maximum viable counts attained before the addition of PMB for the tested 19 strains are shown in Table 4.

The effect of $100 \mathrm{mg} / \mathrm{l} \mathrm{PMB}$ added to red wine was evaluated in the 17 strains displaying maximum viable counts higher than $10^{6} \mathrm{CFU} / \mathrm{ml}$. Fig. 2 shows the behaviour of the abovementioned 4 illustrative strains after PMB addition. Strains ISA 2172 and ISA 2298 resumed growth after the death induced by PMB addition. In opposition, strains ISA 1703 and ISA 2173 did not recover their viability during the course of the experiment. To check the absence of viable cells in the tested wines, the total wine volume was analyzed at the end of the experiment. These two strains did not show the presence of viable or metabolically-active cells. For all 17 strains, the minimum and maximum viable counts determined after PMB addition are shown in Table 4. A total of 7 strains were inactivated by this level of PMB. The populations of the other 10 strains were partially inactivated by $100 \mathrm{mg} / \mathrm{l} \mathrm{PMB}$ and resumed growth after the initial death phase.

Three of the resistant strains isolated from red wines with different origins (ISA 2101 and 2172) and from insects (ISA 2298) were used to study the effect of increasing concentrations of PMB added during different growth phases (Fig. 3). Levels of $150 \mathrm{mg} / \mathrm{l}$ and $200 \mathrm{mg} / \mathrm{l}$ fully killed cell populations during any growth phase of the 3 strains. The addition of $100 \mathrm{mg} / \mathrm{l}$ was

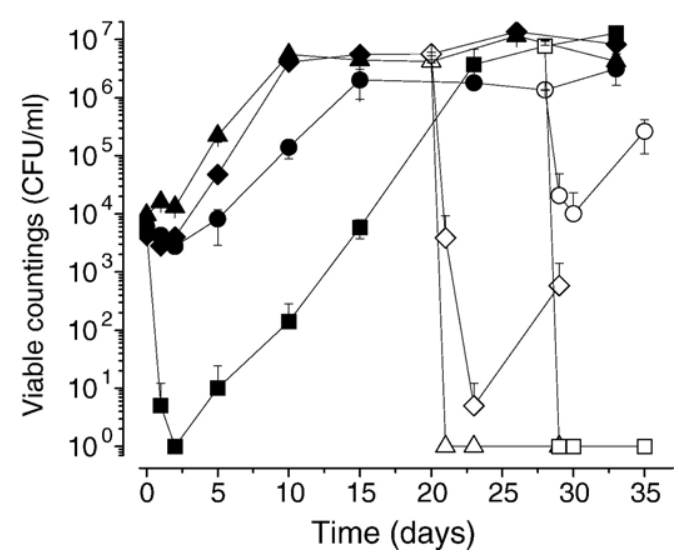

Fig. 2. Effect of the addition of $100 \mathrm{mg} / \mathrm{l}$ of potassium metabisulphite on the viability of several strains of $D$. bruxellensis grown in red wine with $\mathrm{pH} 3.50$ and $12 \%(\mathrm{v} / \mathrm{v})$ of ethanol. Symbols: $(\boldsymbol{\square}, \square)$ ISA $1703 ;(\boldsymbol{\bullet}, \bigcirc)$ ISA $2298 ;(\boldsymbol{\Delta}, \boldsymbol{\Delta})$ ISA 2173; $(\diamond, \diamond)$ ISA 2172. Before sulphite addition: filled symbols; after sulphite addition: open symbols. The value $10^{\circ}$ indicates the absence of colonies in the volume of $0.1 \mathrm{ml}$ of wine sample. 
Table 4

Minimum and maximum viable countings (CFU/ml) of D. bruxellensis strains during growth and after the addition of $100 \mathrm{mg} / 1$ potassium metabisulphite (PMB), in a red wine blend adjusted to $12 \%(\mathrm{v} / \mathrm{v})$ ethanol and $\mathrm{pH} 3.50$

\begin{tabular}{|c|c|c|c|c|}
\hline \multirow[t]{2}{*}{ Strain } & \multicolumn{2}{|c|}{ Before PMB addition } & \multicolumn{2}{|c|}{ After PMB addition } \\
\hline & $\begin{array}{l}\text { Minimum } \\
(\mathrm{CFU} / \mathrm{ml})\end{array}$ & $\begin{array}{l}\text { Maximum } \\
(\mathrm{CFU} / \mathrm{ml})\end{array}$ & $\begin{array}{l}\text { Minimum } \\
(\mathrm{CFU} / \mathrm{ml})\end{array}$ & $\begin{array}{l}\text { Growth } \\
\text { recovery }\end{array}$ \\
\hline 1327 & $5.0 \times 10^{3}$ & $1.6 \times 10^{7}$ & $<10$ & + \\
\hline 1600 & $5.5 \times 10$ & $1.3 \times 10^{7}$ & $2.7 \times 10^{2}$ & + \\
\hline $1649^{\mathrm{T}}$ & $<10$ & $<10$ & $\mathrm{Nd}^{\mathrm{b}}$ & $\mathrm{Nd}$ \\
\hline 1700 & $3.2 \times 10^{2}$ & $1.7 \times 10^{7}$ & $5.5 \times 10^{4}$ & + \\
\hline 1703 & $<10$ & $1.3 \times 10^{7}$ & $<10$ & - \\
\hline 1717 & $4.5 \times 10$ & $1.0 \times 10^{7}$ & $1.3 \times 10^{6}$ & + \\
\hline 1791 & $2.5 \times 10$ & $1.2 \times 10^{7}$ & $<10$ & - \\
\hline 2101 & $5.2 \times 10^{3}$ & $1.4 \times 10^{7}$ & $5.1 \times 10^{4}$ & + \\
\hline 2104 & $1.2 \times 10^{3}$ & $1.3 \times 10^{7}$ & $7.2 \times 10^{4}$ & + \\
\hline 2115 & $3.1 \times 10^{3}$ & $1.3 \times 10^{7}$ & $<10$ & - \\
\hline 2120 & $3.5 \times 10^{3}$ & $4.3 \times 10^{6}$ & $<10$ & - \\
\hline 2121 & $<10$ & $2.5 \times 10^{2}$ & $\mathrm{Nd}$ & $\mathrm{Nd}$ \\
\hline 2128 & $6.7 \times 10^{2}$ & $5.8 \times 10^{6}$ & $3.7 \times 10^{3}$ & + \\
\hline 2132 & $4.0 \times 10^{3}$ & $1.6 \times 10^{7}$ & $6.1 \times 10^{3}$ & + \\
\hline 2172 & $2.8 \times 10^{3}$ & $1.4 \times 10^{7}$ & 10 & + \\
\hline 2173 & $1.3 \times 10^{4}$ & $1.1 \times 10^{7}$ & $<10$ & - \\
\hline 2297 & $1.5 \times 10^{3}$ & $8.7 \times 10^{6}$ & $<10$ & - \\
\hline 2298 & $2.8 \times 10^{3}$ & $3.1 \times 10^{6}$ & $1.0 \times 10^{4}$ & + \\
\hline 2307 & $4.0 \times 10^{3}$ & $9.8 \times 10^{6}$ & $<10$ & - \\
\hline
\end{tabular}

${ }^{\mathrm{a}}(+)$, presence of growth after initial death or lag phase; $(-)$, absence of viable cells until the end of the experiment.

b Not determined.

only effective in the initial growth phase against strains ISA 2172 and 2298. Strain ISA 2101 was partially killed and recovered its viability, being detected at $1.4 \times 10^{4} \mathrm{CFU} / \mathrm{ml}$ after 32 days of incubation.

The effect of cellular wine adaptation on the sulphur dioxide tolerance was mimicked by wine inoculation with cells of strains ISA 2101, 2172 and 2298, previously grown in red wine with $6 \%(\mathrm{v} / \mathrm{v})$ ethanol. All wine-adapted strains showed exponential growth not preceded by a lag phase or initial death upon wine inoculation (results not shown). Wine-adapted cells did not, however, exhibit higher tolerance to PMB added in the early stationary phase (results not shown).

\subsection{Effect of PMB under winery conditions}

The effect of sulphur dioxide was tested in a practical situation where spontaneous $D$. bruxellensis populations may attain high densities, as in the case of wine ageing in oak barrels. Red wines maintained in new oak barrels were monitored for the presence of $D$. bruxellensis at 3 different dates in 2005 (10th June, 23rd July and 20th October). Table 5 shows viable cell counts in different barrels treated with increasing levels of free sulphur dioxide. Only average concentrations above $39-40 \mathrm{mg} / 1$

Fig. 3. Effect of the addition of increasing concentrations of potassium metabisulphite on the viability of D. bruxellensis ISA 2101 (A), 2172 (B) and 2298 (C), grown in wine with $\mathrm{pH} 3.50$ and $12 \%(\mathrm{v} / \mathrm{v})$ of ethanol. Sulphite was added at 3 different times during growth as indicated by the arrows. Symbols: (ם) absence of PMB; $(O)$ after addition of $100 \mathrm{mg} / \mathrm{l} ;(\triangle)$ after addition of $150 \mathrm{mg} / \mathrm{l}$; $(\nabla)$ after addition of $200 \mathrm{mg} / \mathrm{l}$. The value $10^{\circ}$ indicates the absence of colonies in the volume of $0.1 \mathrm{ml}$ of wine sample. were effective in preventing the growth of $D$. bruxellensis, in wine taken from either the upper or lower level of the barrels. In aqueous solutions at $20^{\circ} \mathrm{C}$, the percentage of molecular sulphur dioxide, at $\mathrm{pH} 3.42$, is about $2.5 \%$, which increases with ethanol
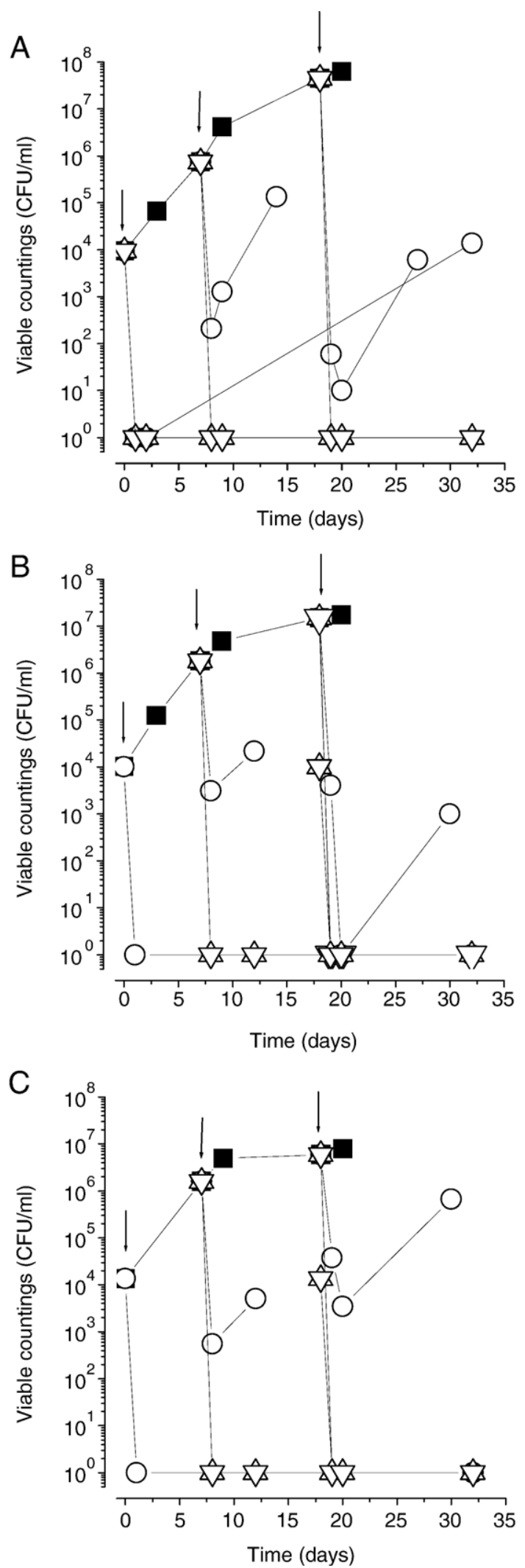
Table 5

Enumeration of Dekkera bruxellensis populations (CFU/ml) during the maturation of red wine (13.8\% ethanol, $\mathrm{pH} 3.42$ ) in new oak barriques under different levels of free sulphite

\begin{tabular}{lllll}
\hline $\begin{array}{l}\text { Free } \mathrm{SO}_{2} \\
(\mathrm{mg} /)^{\mathrm{a}}\end{array}$ & Barriques & \multicolumn{3}{l}{ Sampling date $^{\mathrm{b}}$} \\
\cline { 3 - 5 } & & 10 th June & 23th July & 20th October \\
\hline $29 \pm 6$ & A top & $<1$ & $<1$ & $<1$ \\
& A bottom & $<1$ & $<1$ & 3 \\
$24 \pm 4$ & B top & $<1$ & $<1$ & 2 \\
& B bottom & $<1$ & $<1$ & $3.6 \times 10^{4}$ \\
$26 \pm 6$ & C top & $<1$ & $<1$ & 2 \\
$30 \pm 5$ & C bottom & $<1$ & 1 & $>3.0 \times 10^{4}$ \\
& D & $<1$ & $<1$ & $<1$ \\
$43 \pm 7$ & D bottom & $<1$ & $<1$ & 1 \\
$39 \pm 6$ & E both levels & $<1$ & $<1$ & $<1$ \\
$51 \pm 9$ & F both levels & $<1$ & $<1$ & $<1$ \\
$56 \pm 10$ & G both levels & $<1$ & $<1$ & $<1$ \\
\hline
\end{tabular}

a Average and standard deviation of 5 successive determinations.

b The value $<1$ corresponds to absence of counts after membrane filtration of $100 \mathrm{ml}$ of wine.

content and temperature (Ribéreau-Gayon et al., 2006). Then $40 \mathrm{mg} / \mathrm{l}$ of free sulphur dioxide corresponded to $1 \mathrm{mg} / \mathrm{l} \mathrm{molec}-$ ular sulphur dioxide. The average concentrations of $24-30 \mathrm{mg} / 1$ did not prevent the development of $D$. bruxellensis during the 4 months' storage. In particular, barrel C (under $26 \pm 6 \mathrm{mg} /$ free sulphur dioxide), that showed $1 \mathrm{CFU} / \mathrm{ml}$ at the second sampling date, presented counts higher than $3 \times 10^{4} \mathrm{CFU} / \mathrm{ml}$ after 3 months. The highest counts were observed in two samples taken from the barrels' bottom under $24 \pm 4$ or $26 \pm 6 \mathrm{mg} / 1$ free sulphur dioxide, after 4 months. D. bruxellensis was detected, at the end of the test period, under $29 \pm 6$ and $30 \pm 5 \mathrm{mg} / \mathrm{l}$ of free sulphur dioxide in the bottom level but not in the upper level of the barrels.

\section{Discussion}

The utilization of tolerance screenings in synthetic media enabled the comparison of the behaviour of $D$. bruxellensis with $S$. cerevisiae. This last species, used in wine fermentation, is relatively more tolerant to ethanol and sulphur dioxide than $D$. bruxellensis. The type strain of $B$. anomalus was the most sensitive to ethanol, growing only in the presence of $8 \%(\mathrm{v} / \mathrm{v})$. This higher sensitivity, if valid for a larger number of strains, could explain the absence of this species from wines, as hypothesized by Loureiro and Malfeito-Ferreira (2003). Conterno et al. (2006) also showed that 35 strains of D. bruxellensis grew in the presence of $10 \%(\mathrm{v} / \mathrm{v})$ ethanol, but higher concentrations were not assayed. The ethanol tolerance is believed to be one of the main factors limiting yeast growth in wines. Concerning $D$. bruxellensis, our results in synthetic media indicate that 14.5 to $15.0 \%(\mathrm{v} / \mathrm{v})$ could be considered as the upper level permitting its proliferation in wines. Although we did not succeed in growing cells in wine with ethanol adjusted to $14 \%(\mathrm{v} / \mathrm{v})$ and $\mathrm{pH} 3.50$ under laboratory conditions, we observed growth in real wine with $13.8 \%(\mathrm{v} / \mathrm{v})$ and $\mathrm{pH} 3.42$ matured in oak barrels. This fact suggests that under winery conditions cells are better adapted to overcome the environmental stresses. Overall, those tolerance values agree with the absence of $D$. bruxellensis isolation from high ethanol red wines and from fortified wines (as reviewed by Loureiro and Malfeito-Ferreira, 2003). This observation is also in accordance with empirical experience of sherry wines where increasing ethanol to $15 \%(\mathrm{v} / \mathrm{v})$ prevents D. bruxellensis growth but enables the development of S. cerevisiae film-forming strains (Ibeas et al., 1997). Thus, although relatively tolerant to ethanol, $D$. bruxellensis should be regarded as more sensitive than $S$. cerevisiae.

The results presented in this work explain to a reasonable extent the behaviour of D. bruxellensis populations observed in real wines. The difficulty in obtaining comparable behaviours with equivalent laboratory wine blends corresponds to the empirical observation that some wines, with similar ethanol and $\mathrm{pH}$ values, seem to be more vulnerable to yeast spoilage than others. In particular, white wines induced full cell death when assayed in parallel with red wines (unpublished observations). Thus, the absence of "horse sweat" taint in white wines (Loureiro and Malfeito-Ferreira, 2006) may be explained by its resistance to D. bruxellensis growth. Growth in white wines could only be achieved either by lowering ethanol content or increasing $\mathrm{pH}$ values to unrealistic levels (unpublished observations). Further studies are required to clarify the different cellular behaviour in red and white wines.

In red wines the observed initial death phase and sequential growth have also been reported by Grbin and Henschke (2000) and Du Toit et al. (2005). Fugelsang and Zoecklein (2003) did not notice the existence of a death phase, probably because viable counts were determined on a weekly basis. These authors described two types of growth cycles, one showing a bellshaped pattern, similar to our observations, and the other displaying a second growth phase, ranging from 61 to 712 days' duration. We did not observe this second growth phase, perhaps because of different incubation conditions. The physiological mechanisms underlying the initial death phase should be metabolically different from those of the final death phase owing to the significantly higher proportion of metabolicallyactive cells, evidencing the presence of an active but not culturable population in the final decline phase.

In winery practice sulphur dioxide may be added as PMB aqueous solutions (Ribéreau-Gayon et al., 2006). Our screening results showed that $S$. cerevisiae is considerably more tolerant to PMB than D. bruxellensis. Conterno et al. (2006) presented a tolerance screening using $35 \mathrm{D}$. bruxellensis strains that were able to grow in the range of 10 to $50 \mathrm{mg} / \mathrm{l}$ sulphur dioxide, which correlates well with our results, as we know that PMB yields about $57 \%$ of sulphite (Ribéreau-Gayon et al., 2006). The tolerance tests carried out in red wine showed that $100 \mathrm{mg} / 1$ of PMB was enough to kill about $10^{6}$ cells $/ \mathrm{ml}$ in 7 out of 17 strains, or that $150 \mathrm{mg} / \mathrm{l}$ fully killed 3 of the most resistant strains. The range $100-150 \mathrm{mg} / \mathrm{l} \mathrm{PMB}$ may correspond to about $33-50 \mathrm{mg} / 1$ free sulphur dioxide that at $\mathrm{pH} 3.50$ is equivalent to $0.66-1.0 \mathrm{mg} / \mathrm{l}$ of the active molecular form (Ribéreau-Gayon et al., 2006). This range is in accordance with the value estimated in the winery trial and so we suggest the average value of $1 \mathrm{mg} / \mathrm{l}$ molecular sulphur dioxide to prevent $D$. 
bruxellensis blooms in ageing barrels. Our laboratory tests in static Erlenmeyer flasks seem therefore to be adequate indicators of cellular behaviour under winery conditions. The killing effect of sulphur dioxide was similar when we used the viability measurements by plating and the determination of metabolically-active cells. Thus, contrary to Du Toit et al. (2005), we did not observe the existence of an active but nonculturable population after the addition of sulphur dioxide. In addition, Du Toit et al. (2005) recommended the maintenance of $25-35 \mathrm{mg} / \mathrm{l}$ free sulphur dioxide in bulk wines to prevent $D$. bruxellensis growth. Ribéreau-Gayon et al. (2006) advised the level of $30 \mathrm{mg} / \mathrm{l}$ of free sulphite at $\mathrm{pH} 3.4-3.5$ to eliminate viable $D$. bruxellensis cells. Our results suggest that a higher concentration of sulphur dioxide should be kept to avoid cellular growth. This difference may be explained by the fact that we used yeast populations adapted to wine, at relatively high contamination rates (about $10^{6} \mathrm{CFU} / \mathrm{ml}$ ) in semi-aerobic conditions in Erlenmeyer flasks. Then the level of $1 \mathrm{mg} / \mathrm{l}$ of molecular sulphite may be looked as a yardstick for sulphur dioxide utilization when winemakers are faced with $D$. bruxellensis blooms and corresponds to our winery experience in the prevention of serious infections.

The ability to resume growth after an initial decline during which cells are not detected by plating seems to be a typical behaviour of $D$. bruxellensis. The regular monitoring of these yeasts is essential to prevent the building-up of contaminations, even when past microbial control results are null, because growth may start when conditions become more favourable. The physiological mechanisms underlying this feature are not known. Uscanga et al. (2000) hypothesized that their survival was the result of exceptional resistance to minimal nutrient conditions. Our results showed that D. bruxellensis is no more resistant than $S$. cerevisiae to major inhibitors like ethanol and sulphur dioxide and so, probably, the mechanisms underlying the ability to survive in nutritionally-poor environments is the key to explain their proliferation when the environment becomes less stressing.

\section{Acknowledgements}

The research work was supported by FCT and by POCI 2010 (project POCI/AGR/ 56771/2004), under the frame of the European Fund FEDER.

\section{References}

Chatonnet, P., Boidron, J., Dubourdieu, D., 1993. Influence des conditions d'élevage et de sulfitage des vins rouges en barriques sur le teneur en acide acétique et en ethyl-phenols. Journal International Sciences de la Vigne et du Vin 27, 277-298.

Chatonnet, P., Dubourdieu, D., Boidron, J.N., Pons, M., 1992. The origin of ethylphenols in wines. Journal of the Science of Food and Agriculture 60, $165-178$.
Ciolfi, G., 1991. Ecologia dei lieviti vinari. Vini d'Italia 33, 41-46.

Conterno, L., Joseph, C.M.L., Arvik, T.J., Henick-Kling, T., Bisson, L.F., 2006. Genetic and physiological characterization of Brettanomyces bruxellensis strains isolated from wines. American Journal of Enology and Viticulture 57, 139-147.

Dias, L., Pereira-da-Silva, S., Tavares, M., Malfeito-Ferreira, M., Loureiro, V., 2003. Factors affecting the production of 4-ethylphenol by the yeast Dekkera bruxellensis in enological conditions. Food Microbiology 20, 377-384.

Du Toit, W.J., Pretorius, I.S., Lonvaud-Funel, A., 2005. The effect of sulphur dioxide and oxygen on the viability and culturability of a strain of Acetobacter pasteurianus and a strain of Brettanomyces bruxellensis isolated from wine. Journal of Applied Microbiology 98, 862-871.

Froudière, I., Larue, F., 1989. Conditions de survie de Brettanomyces (Dekkera) dans le mout de raisin et le vin. Actualités Oenologiques (Séances du Symposium International d'Oenologie). Dunod, Bordeaux, France, pp. 297-303.

Fugelsang, K., Zoecklein, B., 2003. Population dynamics and effects of Brettanomyces bruxellensis strains on Pinot noir (Vitis vinifera $\mathrm{L}$.) wines. American Journal of Enology and Viticulture 54, 294-300.

Gaia, P., 1987. Caraterizzazione tassonomica ed enologica de lieviti anomali fonte di inquinamento dei vini. Annali dell'Istituto Sperimentale per l'Enologia Asti 18, 290-305.

Gerbaux, V., Vincent, B., Bertrand, A., 2002. Influence of maceration temperature and enzymes on the content of volatile phenols in Pinot noir wines. American Journal of Enology and Viticulture 53, 131-137.

Godden, P., Gishen, M., 2005. Trends in the composition of Australian wine. The Australian and New Zealand Wine Industry Journal, 20 5, 21-46.

Grbin, P.R., Henschke, P.A., 2000. Mousy off-flavour production in grape juice and wine by Dekkera and Brettanomyces yeasts. Australian Journal of Grape and Wine Research 6, 255-262.

Heresztyn, T., 1986. Metabolism of volatile phenolic compounds from hidroxycinnamic acids by Brettanomyces yeast. Archives of Microbiology 146, 96-98.

Ibeas, J.I., Lozano, I., Perdigones, F., Jimenez, J., 1997. Effects of ethanol and temperature on the biological aging of sherry wines. American Journal of Enology and Viticulture 48, 71-74.

Kurtzman, C.P., Fell, J.W (Eds.), 1998. The Yeasts, A Taxonomic Study, 4th edition. Elsevier, Amsterdam.

Loureiro, V., Malfeito-Ferreira, M., 2003. Spoilage yeasts in the wine industry. International Journal of Food Microbiology 86, 23-50.

Loureiro, V., Malfeito-Ferreira, M., 2006. Spoilage activities of Dekkera/ Brettanomyces spp. In: Blackburn, C. (Ed.), Food Spoilage Microorganisms. Chapter 13. Woodhead Publishing Limited, Cambridge, England, pp. 354-398.

Ribéreau-Gayon, P., Dubourdieu, D., Donèche, B., Lonvaud, A., 2006. 2nd ed. Handbook of Enology. The Microbiology of Wine and Vinifications, 1. John Wiley and Sons, Ltd, Chichester, England.

Rodrigues, N., Gonçalves, G., Malfeito-Ferreira, M., Loureiro, V., 2001. Development and use of a differential medium to detect yeasts of the genera Dekkera/Brettanomyces. International Journal of Food Microbiology 90, 588-599.

Suárez, R., Suárez-Lepe, J.A., Morata, A., Calderón, F., 2007. The production of ethylphenols in wine by yeasts of the genera Brettanomyces and Dekkera. A review. Food Chemistry 102, 10-21.

Thomas, D., Hossack, J., Rose, A., 1978. Plasma-Membrane lipid composition and ethanol tolerance in Saccharomyces cerevisiae. Archives of Microbiology 117, 239-245.

Uscanga, M., Delia, M.L., Strehaiano, P., 2000. Nutritional requirements of Brettanomyces bruxellensis: growth and physiology in batch and chemostat cultures. Canadian Journal of Microbiology 46, 1046-1050.

Van der Walt, J.P., van der Kerken, A.E., 1961. The wine yeasts of the Cape. Part V. Studies on the occurrence of Brettanomyces schanderlii. Antonie Leeuwenhoek 27, 81-90. 